\title{
Saphenous nerve entrapment manifested as proximal cruralgia
}

\author{
General Hospital of the Medical Science Faculty, \\ State University of Campinas, UNICAMP - Campinas, Brazil
}

\begin{abstract}
A 16 year old boy had continuous pain in the right testis, groin, and the medial aspect of the thigh and knee for 16 months. The onset of symptoms was acute and pain distribution included a retrograde area in relation to the entrapment site. Tinel's sign was the clue for diagnosis. Diagnosis was confirmed at operation and division of the aponeurosis of Hunter's canal relieved the symptoms for three days. A second surgical exploration, proximal to the former one, was performed after five months. The right femoral nerve was found normal. This new operation was therapeutically ineffective. Causes of pain distribution and relapsed pain are discussed. The relapse was attributed to myofascial pain syndrome. This diagnosis should be considered independently of the correct treatment of the primary lesion.
\end{abstract}

UNITERMS: Saphenous entrapment neuropathy. Surgical saphenous neurolysis. Myofascial pain syndrome. Trigger points.

\section{INTRODUCTION}

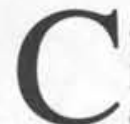
ases of saphenous nerve entrapment have been published because of their rarity, difficult diagnosis and variety of symptoms. They may simulate vascular disorder ${ }^{2}$, lumbar radiculopathy ${ }^{3}$ and knee joint lesion ${ }^{45,6}$. The case which follows raised doubts and taught lessons the authors would like to share with the readers.

\section{CASE REPORT}

A 16 year old boy was first seen at UNICAMP as an outpatient in January 1988. He complained of having had pain in the right leg for 8 months. Its onset was abrupt during

\section{Adress for correspondence:}

João Neves Camargo Jr.

Rua Barros Monteiro, 134, Jd. Guanabara

Campinas/SP - Brasil - CEP 13073-240 a bout of coughing. The pain was lancinating and burning in the right testis and groin, radiating to the medial aspect of the right thigh and knee. This pain was continuous, exacerbated by any movement of the right lower limb. A fall from a horse 3 months before the beginning of symptoms was reported. The patient walked with crutches, just touching the right forefoot on the floor, keeping the ankle joint in equinus position, the knee joint in light flexion and the hip joint adducted, flexed and externally rotated. The lower back region and right adductor muscles were painful when palpated. A superficial sensory deficit was noted, extending from the right groin through the medial side of the thigh down to the tibial maleolus. Urinalysis, routine blood analysis, cerebrospinal fluid examination, abdomino-pelvic ultrasonography, conventional radiography for spine, pelvis and knee, skeleton scintigraphy, CT of spine and pelvis and electromyography did not contribute to the diagnosis. The measurement of saphenous conduction velocity this case would require was beyond our reach at that time. In June 1988 a Tinel's sign was detected on the medial aspect of the distal third of the right thigh and a positive inverse Lasègue's sign was found.

In August 1988 the right saphenous nerve was surgically explored and neurolysis performed (fig.1). The only 


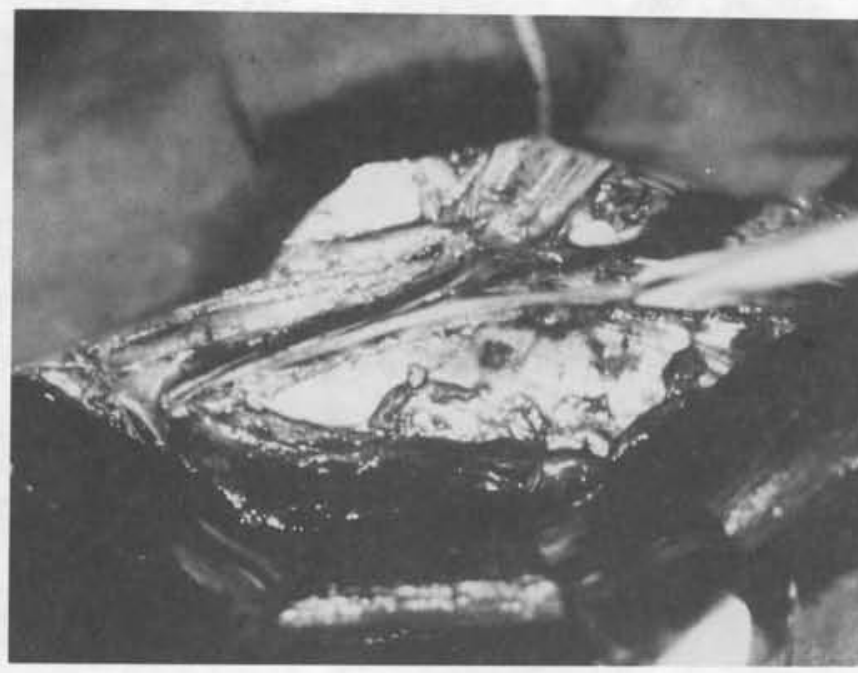

Figure 1 - Saphenous nerve (S.N.) after longitudinal division of the aponeurotic wall of Hunter's canal. S.N. is held with a Penrose drain. Retractors are pulling the sartorius muscle. A pad protects the vastus medialis muscle.

constringency found was at the point where the nerve pierced the Hunter's canal aponeurosis. In the post-operative period the patient, relieved from pain, could walk and even climb stairs. From the 4 th post-operative day onwards, symptoms recurred, although less severely. In September 1988 the patient was back on crutches. Gentle stretching of the affected muscles, and Amitriptyline and Phenylbutazone were ineffective. In January 1989 pain was mainly felt in the right testis and groin. A second surgical exploration was then perfomed, from the upper end of the former one up to the inguinal ligament. The femoral nerve was normal. Carbamazepine, Paracetamol and "Cronassial" proved useless. In 1990 the patient could walk without crutches again. Since 1992 he has been asymptomatic.

\section{DISCUSSION}

Nerve lesion was found about $10 \mathrm{~cm}$ above the right knee joint. Could pain in the right testis and groin, present from the very onset of symptoms, be explained by an overflow in the internuncial pool caused by impulses from saphenous nerve stimulation, giving rise to sensations which originated in more proximal portions of this nerve and its anastomosis? . $^{4}$

Three days without pain, relief of pain with rest and lack of response to Carbamazepine rule out de-afferentation as a cause of relapsed pain ${ }^{7}$. Sixteen months elapsed between the onset of symptoms and neurolysis. During that period of time the right lower limb was kept in a non-physiological position, which must have caused a myofascial pain syndrome. The recurrence of pain almost certainly developed from trigger points ${ }^{1}$ that should have been identified and inactivated at that time. The second operation was clearly unnecessary. Psychiatric treatment, wisely refused by the patient, would also have been redundant.

\section{Resumo}

Um rapaz de 16 anos apresentava dor contínua no testículo, região inguinal, face medial da coxa e joelho direitos há 16 meses. O começo do quadro foi repentino $\theta$ a maior parte dos sintomas era proximal à lesão. O diagnóstico foi feito ao se detectar o sinal de Tinel e confirmado na cirurgia. A abertura longitudinal do canal de Hunter, liberando o nervo na sua emergência do mesmo provocou a cessação da dor por três dias. Cinco meses depois da primeira, procedeu-se a uma nova exploração cirúrgica, proximal à anterior, que revelou o nervo femoral direito normal e não teve qualquer efeito terapêutico. As causas da localização e da recidiva dos sintomas são discutidas. Os autores atribuem a recidiva da dor à síndrome da dor miofascial, diagnóstico a ser lembrado independentemente do tratamento correto da lesão primária.

\section{REFERENCES}

1. Simons DG. Fibrositis / Fibromyalgia: a form of myofascial trigger points? Am J Med 1986; 81 (suppl 3A): 93-98.

2. Mozes M, Quaknine G, Nathan H. Saphenous nerve entrapment simulating vascular disorder. Surgery 1975; 77 : 299-303.

3. Saal JA, Dillingham MF, Gamburd RS, Fanton GS. The pseudoradicular syndrome. Spine 1988; 13: 926-930.
4. Kopell HP, Thompson WAL. Knee pain due to saphenous nerve entrapment. New Eng J Med 1960; 263: 351-353.

5. Romanoff M E, Cory JR PC, Kalenak A, Keyser GC, Marshall WK. Saphenous nerve entrapment at the adductor canal. Am J Sports Med 1989; 17: 478-481.

6. Worth RM, Kettelkamp DB, Defalque RJ, Duane KU. Saphenous nerve entrapment. A cause of medial knee pain. Am J Sports Med 1984; 12: 80-81.

7. Bouchez B, Arnott G, Delandsheer E, Blond S, Guieu JD. Neuropathie crurale avec douleurs de déafferentation. Acta neurol belg 1985; 85: 269-276. 